\title{
Women's Leadership and Pragmatism Incidences on Performance of Listed Family-Owned Firms in the Cultural Context of Arab Countries
}

\author{
Azzeddine Allioui ${ }^{1}$, Badr Habba ${ }^{1,2} \&$ Taib Berrada El Azizi ${ }^{2}$ \\ ${ }^{1}$ LAREGO Laboratory, ENCG, Cadi Ayyad University, Marrakesh, Morocco \\ ${ }^{2}$ Chair of Moroccan Family Businesses, ESCA Ecole de Management, Casablanca, Morocco \\ Correspondence: Azzeddine Allioui, LAREGO Laboratory, ENCG, Cadi Ayyad University, Marrakesh, Allal El Fassi, \\ BP 3748, Morocco. E-mail: azzeddine.allioui@ gmail.com
}

Received: December 7, 2020

doi:10.5430/ijfr.v12n3p251

URL: https://doi.org/10.5430/ijfr.v12n3p251

\begin{abstract}
This research paper aims to study the level and determinants of the financial performance of family businesses, according to the gender of the board of directors' chairman in the Arab world. Our research approach is based on a sample of 152 listed family-owned businesses and a control sample of 166 listed non-family businesses over the 2011-2018 periods. The research results indicate that the female gender issue has a positive influence on the financial performance of businesses with family ownership. This is explained by the fact that women leaders have a prudent and pragmatic leadership style that limits stereotypical images of women presidents' leadership style in the Arab world. This result is original since it can be considered as the first one to ever clarify the relationship between female leadership in the board of directors, risk-taking, and financial performance in the context of family ownership in the Arab countries.
\end{abstract}

Keywords: family business, female leadership, women's leadership, transformational leadership, financial performance, risk-taking

\section{Introduction}

Leadership has been the subject of many contributions and various managerial researches. Among them, work that aims to provide an overview of leadership styles and identify the most relevant models for organizations in cultural contexts. However, the analyses carried out remain asexual and are mostly applied to a sample of men who were once fully involved in top management functions. Another style of comparative research on the leadership styles mobilized by men and women in management positions has aroused great interest, to identify the different issues concerning the dominant management styles of both sexes, and to note the characteristics of the representation of women in this type of position (Palvia, E.Vähämaa, \& S. Vähämaa, 2015; Salloum, Jabbour, \& Mercier-Suissa, 2019).

To this end, practical measures have been taken, and several countries have introduced legislation to promote quotas for women. The example of France, which since 2011 has adopted a law called "Copé-Zimmermann", to realize gender equilibrium in management bodies by setting the objective of reaching $40 \%$ of one of the two sexes on the board of directors to promote equal opportunities for access to major positions of responsibility. Also, in the United States, there is a very low representation of women presidents, which does not exceed 5\% (Catalyst, 2012). Accordingly, the EOWA agency notes that only $3.5 \%$ of businesses had a director, and only $3 \%$ had a female president. Also, barriers and stereotypes based on sex in management are more acute in the Arab world. Arab countries present few opportunities for women to succeed in winning presidential positions. The UN women report (2018) shows a low rate of integration of women in the economic activity of companies in this region of the world: 26.74\% in Morocco, against 27.08\% in Tunisia, 16, 85\% in Algeria, and around 28\% in Saudi Arabia (of which only $2 \%$ hold CEO positions). These rates are lower compared to the world average of $53.7 \%$.

While it is approved by the practice in the field that women meet more problems to obtain high positions (Oakley, 2000), family-owned businesses allow them to make great achievements in the company and the family. Smith, Smith, \& Verner (2006) claim that women can be nominated because of their strong relationships with the owners' family-owned businesses. Also, in the Arab countries, the sample of our empirical study shows clearly that the 
proportion of women presidents is lower in family firms, approving that the selection of female presidents is rather negatively impacted by family habits and cultural specificities than a normal selection process.

However, granting the position of the board of directors' chairman to a woman can reveal positive consequences for the performance of family businesses. This proposition is explained by the positive intersection between the characteristics of the female gender and the socioemotional specificities of family businesses. Indeed, women present a spirit of active listening, communication, and wisdom at the level of decisions taken in the management sphere (Chapple \& Humphrey, 2014). These characteristics are consistent with the specificity of family businesses which increasingly captures the emotional bond that shareholders of family businesses feel towards their businesses, and with their employees. Bammens, Voordeckers, \& Van Gils (2011) debate the positive impact of emotional effects on moral, psychological, behavioral, and management aspects in family-owned businesses. In this sense, non-financial objectives are of great significance in the case of decision making by these firms (Gomez-Mejía, Haynes, Núñez-Nickel, Jacobson, \& Moyano-Fuentes, 2007; Gomez-Mejia, Cruz, Berrone, \& De Castro, 2011; Bammens and al., 2011). The leadership style suited to this form of business should be based on personal and social values. Indeed, female leaders use a style that can spread values and family culture, that is adequate to the mission of the family business and its objectives (Vallejo, 2009).

As a result, and although the family business is effective in promoting female leadership (Smith and al., 2006), there is no study on the effects of the board's president gender on the financial performance of family-owned businesses in the context of the Arab region. Our article will respond to the question: What is the effect of women's leadership at the presidential positions on the financial performance of family-owned businesses in Arab countries?

To answer this research question, we are conducting an empirical study based on a sample made up of 152 family businesses, and a control sample made up of 166 non-family businesses, over the 2011-2018 period. The first step of the empirical study verifies the difference between the performance of family businesses chaired by women and those chaired by men, and, between family-owned and non-family firms chaired by women. Then, the second phase studies the determinants of this performance in the different samples based on a multifactorial model through the econometrics of panel data.

In this article, first, we will highlight our review of the literature on the details of the leadership style of female and male presidents. These differences are based on the contingency theory of leadership, and theoretical developments on socioemotional wealth in family businesses. Then, we develop empirical hypotheses on the effect of female chairmanship on the performance of family-owned and non-family firms. Secondly, we present our methodology and our results analysis. And finally, we discuss and conclude on the important implications of gender leadership on the governance of family-owned firms in the context of the Arab countries.

\section{Literature Review and Hypothesis Development}

Several studies based on the theory of leadership contingency show the effects of women's distinctive leadership style on performance (Paragraph 2.1), and even more, with more acuity in the specific case of family businesses (Paragraph 2.2).

\subsection{The Distinctive Effects of the Female Leadership Style of the Chairman of the Board on Performance}

The theory of leadership contingency underpins work on the effects of the leadership style of the board's chairman on performance. In this context, several studies have focused on the distinctive leadership styles of women (Rosener, 1990; Bass, 1999; Eagly \& Carli, 2012; Dezso \& Ross, 2012).

Men focus on a style that prioritizes task execution, while women focus on a style that prioritizes interaction, which is more suited to the transformational style (Eagly \& Carli, 2012; Shen \& Joseph, 2020). Thus, the authors agree that women are more successful because they play social roles in the company (Shen \& Joseph, 2020). For example, women follow democratic and friendly styles, while male presidents should exhibit rigid, assertive, and masterful qualities. So, differential effects can occur in a presidential position (Shen \& Joseph, 2020). The two styles, transformational and transactional, should be considered separately, especially when they are treated from a gender perspective (Eagly \& Carli, 2012).

Furthermore, the presidents' leadership style is undeniably decisive for business performance. In this sense, and to be an effective leader in terms of business performance, some behaviors are more relevant and effective than others. As a result, a style that is particularly effective in inspiring the actions of board members is transformational leadership (Eagly \& Carli, 2012). In this context, several authors assert that the transformational style is more adopted by women presidents (Bass, 1999). 
Some authors indicate that women have the potential to deal with the complexity of the business environment (Rosener, 1990; Eagly \& Carli, 2012). Otherwise, firms where women use an autocratic style perform less than others (Zhang, Li, Ullrich, \& van Dick., 2015).

Remarkably, Zhang and al. (2015) report that transformational leadership is positively linked both to the effectiveness of the top management and to the achievement of the performance objectives. For example, if a woman president voluntarily develops friendly relationships with senior managers at the top of management, this behavior can be considered a source of motivation. This is consistent with the specificities of the female gender in terms of cooperation (Zhang and al., 2015). The positive effect of differentiated leadership on the efficiency of the management team and the performance of companies will then be improved (Zhang and al., 2015).

Based on the combination of these arguments, we believe that women are effective leaders because they adopt interpersonal ability and transformational leadership style, as the main criteria needed in the presidential position.

Based on the above, we expect the assertion of a first hypothesis formulated as follows:

H1: There is a positive relationship between female leadership at the level of the chairmanship of the board of directors and the performance of listed family businesses in Arab countries.

\subsection{The Style of Female Leadership: Differences Between Family-Owned and Non-family Business}

The effectiveness of the leadership style can vary, as contingency theory shows, depending on the type of the company and the values in which the president's work (Fiedler, 1967; Jayawardena, 2012). Indeed, leadership studies focus on organizational facts and ignore cultural facts. Therefore, we discuss another dimension of contingency theory: leadership gender in family-owned businesses. The objective is to test the prevalence of leadership contingency theory by taking into account the female leadership positions in family-owned and non-family businesses.

Within this framework, researchers recognizing the influence of socio-emotional wealth on all aspects related to the management of family business (Bammens and al., 2011; Gomez-Mejia and al., 2011; Labaki, Michael-Tsabari, \& Zachary, 2013; Debicki, Randolph, \& Sobczak, 2017). In this sense, the position of the president is practiced differently in family-owned companies and their non-family counterparts. Therefore, according to the contingency theory of leadership, the transformational style is more appropriate for family businesses, and this style is generally adopted by women.

The presence of non-financial objectives (trust, conflicts management) in the specific context of family-owned businesses has an impact on the strategies of the board of directors (Bammens and al., 2011), and the conservatism of the firm (Basly, 2007). Consequently, the chairman in family businesses should make attention to providing advice. In other words, they should adopt a transformational rather than a transactional style.

The primary task of the board's chairman in the family business is advisory (Bammens and al., 2011). The second advisory task pushes the chairman in family-owned businesses to manage conflicts of interest linked to performance objectives and strategies (Bammens and al., 2011; Allioui, Habba, and El Azizi, 2020). For example, transformational chairs of the board of directors adopt a leadership style that stimulates member's skills to engage in more objective discussions and promote more balanced perspectives.

In this context, women presidents are considered more effective in family-owned businesses and make a difference in the meeting room. The female presidents focus on collective leadership style in the meeting room, by adopting problem-solving and active listening skills Consequently, they can improve decision-making in family businesses.

Based on the arguments we have just mentioned, we expect that at the level of family businesses, the female presidents will be better able to adopt transformational leadership. Indeed, the prevalence of counseling tasks by women in family businesses ensures the protection of socioemotional wealth through an increase in the performance of family businesses (Nekhili, Chakroun, \& Chtioui, 2018).

Based on these arguments, we expect the assertion of a second hypothesis formulated as follows:

H2: The positive impact of women's leadership at the position of the chairman of the board of directors on performance is greater in listed family-owned businesses than in listed non-family businesses in Arab countries.

Finally, the objective of our literature review was to synthesize previous research on women's leadership in relation to performance in the context of family businesses. On the one hand, this review allowed us to elaborate the hypotheses of our research that will be tested later. On the other hand, this literature review shows clearly that the previous research has a lot of insufficiencies to explain the impact of women's leadership on financial performance in 
a context with a double specificity. First, a specificity of the type of family business that is very rarely studied when it comes to the relationship between women's leadership and financial performance. And secondly, a specificity of the Arab cultural context that presents many stereotypes on women's leadership, and which is unexplored when it comes to research conducted on family businesses and relating the specificities of women's leadership to the specificities of the financial performance of family businesses in an emerging context (the Arab context).

\section{Method}

Our research is positioned in positivist logic while following a hypothetico-deductive reasoning and a quantitative approach on a sample of 152 family businesses and 166 non-family businesses selected based on their size in the Orbis database. This sample allows us to analyze 35,616 annual panel data between 2011 and 2018. These companies come from 13 Arab countries (Algeria, Bahrain, Egypt, Iraq, Jordan, Kuwait, Morocco, Oman, Qatar, Saudi Arabia, Syria, Tunisia, and the Arab Emirates). The criteria for defining a family business are that a family must control at least $50 \%$ of the shares of the company (Leach, 1990).

Then, the first phase of the empirical study consisted of examining the study hypotheses based on tests of the hypotheses on the medians for the independent samples. The aim is to compare the financial performances between the family businesses headed by women and men. Also, between family and non-family businesses chaired by women.

Secondly, we studied the determinants of this performance based on the econometrics of panel data methodology. The objective of this study was to identify the determinants of financial performance according to the board of directors' chairman gender.

The dependent variable used in our study to measure performance is the ROA proxy, in line with our initial questioning stating that the board's chairman is supposed to create value for all stakeholders, and therefore, we will empirically test the performance of the whole assets. The empirical model of this paper is founded based on the empirical works illustrated in (Table 1):

Performance $_{i t}=\beta 0+\beta 1\left(\mathbf{T}_{-} \mathbf{Q}\right)_{\mathrm{it}}+\beta 2\left(\mathbf{E F F}_{-}\right)_{\mathrm{it}}+\beta 3\left(\mathbf{F i n} \_\mathbf{B a}\right)_{\mathrm{it}}+\beta 4\left(\mathbf{F i n} \_ \text {Indep }\right)_{\mathrm{it}}+\beta 5\left(\mathbf{L e v}_{-}\right)_{\mathrm{it}}+\beta 6\left(\mathbf{L i q}_{-}\right)_{\mathrm{it}}+\beta 7$

$$
\left(\text { Size }_{-}\right)_{\mathrm{it}}+\beta 8\left(\mathbf{S} \_ \text {Gro }\right)_{\mathrm{it}}+\beta 9(\overline{\text { Pre_Invest }})_{\mathrm{it}}+\beta 10(\text { Cap_Turn })_{\mathrm{it}}+\beta 11(\text { Pre_ROA })_{\mathrm{it}}+\varepsilon \mathrm{t}
$$

With:

Table 1. Description of quantitative variables

\begin{tabular}{|c|c|c|c|}
\hline Variable & Calculations & Empirical foundation & Coding \\
\hline ROA & Net income / total assets & \multirow{5}{*}{ Allouche, Amann \& Garaudel (2007) } & ROA \\
\hline Efficiency & $\begin{array}{l}\text { Earnings Before Interest and } \\
\text { Taxes / Turnover }\end{array}$ & & $\mathrm{EFF}_{-}$ \\
\hline Financial balance & liabilities / Tangible assets & & Fin_Ba \\
\hline Financial independence & $\begin{array}{l}\text { Equity/liabilities } \\
\text { stockholders' equity }\end{array}$ & & Fin_Indep \\
\hline Liquidity ratio & $\begin{array}{l}\text { Current assets / Short-term } \\
\text { debts }\end{array}$ & & $\mathrm{Liq}_{-}$ \\
\hline Tobin's Q & Market value / Book value & Maury (2006) & T_Q \\
\hline Size of the firm & Log (total assets) & \multirow{3}{*}{ Capon, Farley, \& Hoenig (1990) } & Size \\
\hline Sales of growths & $\begin{array}{l}\text { Increase in turnover from } \\
(\mathrm{N}-1) \text { to } \mathrm{N}\end{array}$ & & S_Gro \\
\hline Investment in $\mathrm{N}-1$ & Investment of previous year & & Pre_Invest \\
\hline Leverage ratio & Total debts / Total assets & \multirow{3}{*}{ Gottardo \& Moisello (2015) } & $\mathrm{Lev}_{-}$ \\
\hline Capital Turnover & Sales / Capital & & Cap_Turn \\
\hline Previous ROA & ROA (N-1) & & Pre_ROA \\
\hline
\end{tabular}


Before starting the panel tests, we examined the probable existence of multi-collinearity problems between the explanatory variables of the model. This resulted in allowing us to integrate the variables in the following tests. Then, we tested the data based on the panel data method by testing two models (fixed effects and random effects). Subsequently, tests are carried out to check individual heterogeneity and have made it possible to accept it in the case of the two models (Fisher test to check the significance of the fixed effects and the Breush-Pagan test to test the significance of the random effects). Furthermore, the Hausman specification test allowed us to accept the hypothesis of independence between unobserved individual heterogeneity and the explanatory variables, which presents more robust results.

\section{Results and Discussion}

According to the theory of leadership contingency, we believe that women are effective leaders because they adopt a transformational management style, which is more appropriate to the characteristics of the family businesses and tends to generate better results. Consequently, the assumptions of our paper allowed us to compare ROA, and test the proposed model on three samples based on two comparisons:

- Family businesses chaired by women (EFWC), and family businesses chaired by men (EFMC).

- Family businesses chaired by women (EFWC), and non-family businesses chaired by women (ENFWC).

The results produced by this study through the hypothesis tests are first presented and discussed in (Section 4.1), and the results of panel econometrics on the empirical model are presented secondly in (Section 4.2).

4.1 Analysis and Discussion of the Hypothesis Tests Results: The Positive Effect of Women's Style of Leadership on the Performance of Family Businesses

The results generated by this study based on hypothesis testing are presented in the following table based on the Kruskal-Wallis test and the hypothesis $\mathrm{H} 0$ that indicate that the distribution of the median is identical between all the samples:

Table 2. Comparative results based on the Kruskal-Wallis test

\begin{tabular}{llllll}
\hline & \multicolumn{3}{l}{ Median values } & \multirow{2}{*}{ Significance } & \multirow{2}{*}{ Result } \\
\cline { 2 - 5 } & ENWC & EFMC & ENFWC & & \\
\hline Performance (ROA) & 4.43 & 4.24 & 2.45 & .002 & $\mathbf{H}_{\mathbf{0}}$ rejected \\
\hline
\end{tabular}

The significance is valid if $\mathrm{p}<0.05$

First, and based on the theory of transformational leadership, hypothesis 1 suggests in principle that there is a positive effect of women's leadership on the performance of family-owned businesses. In parallel, and based on the interpersonal qualities required for the chairman in family-owned businesses, hypothesis 2 specifies that female style is in positive relation with the performance of family-owned companies related to non-family businesses. In this context, our results of non-parametric tests corroborate these hypotheses in the context of the Arab countries. The corroboration of hypotheses $\mathrm{H} 1$ and $\mathrm{H} 2$ (Table 2) is made based on the ROA showing that family businesses chaired by women outperform both family businesses chaired by men and non-family businesses chaired by women.

Interpretatively, our hypothesis test results indicate that female presidents in family-owned businesses high-perform male presidents, and also their counterparts in non-family businesses. We explain this result by their transformational style (Eagly \& Carli, 2012; Dezso \& Ross 2012), consistent with the characteristics of family businesses because transformational leaders spread, more efficiently, the family culture and its objectives (Vallejo, 2009).

More specifically, the chairman in family-owned businesses should make attention to allocating managerial than supervisory advisory tasks, and on boosting the skills of board members, so that they can add value to the professional skills (Bammens and al., 2011).

Besides, the variances in gender performance may be due to the process of appointing the president. Consistent with the widely held assumption about family business recruiting practices (Burkart, Panunzi, \& Shleifer, 2003), the selection of female presidents are probable to be linked to social bonds with family business holders who want to guarantee sustainability. In the same, the second argument states that the president is chosen from a small set of management talents in family businesses (Smith and al., 2006), because women can meet the needs of family businesses, and manage their boards better than men, since they are more effective, which increase the business 
performance (Eagly \& Carli, 2012).

4.2 Analysis and Discussion of the Model's Results: The Inherent Impact of Family Ownership and Risk Aversion by Women Presidents

This second stage of our study consists of testing a model with several explanatory variables to study the determinants of performance in each sample. The results are set out in the table below:

Table 3. Results of the determinants of ROA proxy

\begin{tabular}{|c|c|c|c|}
\hline Independent variables & $\begin{array}{l}\text { Family businesses } \\
\text { chaired by women }\end{array}$ & $\begin{array}{l}\text { Family businesses } \\
\text { chaired by men }\end{array}$ & $\begin{array}{l}\text { Non-family businesses } \\
\text { chaired by women }\end{array}$ \\
\hline \multirow[t]{2}{*}{ T_Q } & 0.0482 & 0.303 & $0.733 * * *$ \\
\hline & $(0.0900)$ & $(0.158)$ & $(0.132)$ \\
\hline \multirow[t]{2}{*}{$\mathrm{EFF}_{-}$} & $13.87 * * *$ & $17.51 * * *$ & $16.54 * * *$ \\
\hline & (1.677) & (2.414) & (1.396) \\
\hline \multirow[t]{2}{*}{ Fin_Ba } & -2.678 & $-11.04 * * *$ & 2.244 \\
\hline & $(4.426)$ & (3.920) & $(2.723)$ \\
\hline \multirow[t]{2}{*}{ Fin_Indep } & $9.511 * * *$ & $19.57 * *$ & 4,932 \\
\hline & (3.624) & (9.498) & (3.263) \\
\hline \multirow[t]{2}{*}{ Lev $_{-}$} & 8.549 & 47.82 & -2.635 \\
\hline & (11.64) & (18.80) & $(6.545)$ \\
\hline \multirow[t]{2}{*}{ Liq $_{-}$} & $-0.223 * * *$ & -0.0720 & 0.339 \\
\hline & $(0.0672)$ & $(0.184)$ & $(0.319)$ \\
\hline \multirow[t]{2}{*}{ Size_ } & -2.050 & -0.607 & 0.730 \\
\hline & $(1.920)$ & $(1.905)$ & $(1.737)$ \\
\hline \multirow[t]{2}{*}{ S_Gro } & 0.621 & 0.246 & -0.124 \\
\hline & $(0.478)$ & $(0.431)$ & $(0.220)$ \\
\hline \multirow[t]{2}{*}{ Pre_Invest } & 0.00359 & -0.110 & 0.134 \\
\hline & $(0.203)$ & $(0.142)$ & $(0.111)$ \\
\hline \multirow[t]{2}{*}{ Cap_Turn } & $0.568 * * *$ & -0.0684 & $1.225 * * *$ \\
\hline & $(0.164)$ & (0.112) & (0.236) \\
\hline \multirow[t]{2}{*}{ Pre_ROA } & $0.252 * * *$ & $0.200 * * *$ & 0.0394 \\
\hline & $(0.0635)$ & $(0.0657)$ & $(0.0397)$ \\
\hline \multirow[t]{2}{*}{ Constant } & 2,696 & -11.19 & -14.12 \\
\hline & $(10.02)$ & $(12.57)$ & $(8.960)$ \\
\hline R square & 0.601 & 0.382 & 0.755 \\
\hline Fisher test & 0.0000 & 0.0000 & 0.0000 \\
\hline Breush-Pagan test & 0.1860 & 1,000 & 0.0000 \\
\hline Endogenity test (Hausman) & 0.0000 & 0.0000 & 0.0000 \\
\hline
\end{tabular}


The tests' results allowed us to conclude on two essential points. A first reading brings us to highlight the comparison between family businesses chaired by women and men. Therefore, efficiency, financial independence, and past performance have a significant positive effect on both categories.

Besides, the discriminatory effects between the two samples are represented by the positive significance of growth opportunities, and the negative significance of financial balance for family businesses chaired by men compared to those chaired by women.

Then, the second analysis of the panel tests is completed based on the comparison between family and non-family businesses chaired by women. In this context, efficiency and capital turnover are positively significant for the two classes. Besides, the discriminatory effect between the two is represented by the positive significance of growth opportunities for non-family businesses chaired by women, and the positive significance of financial independence and past performance for family businesses chaired by women.

In sum, this paper shows two original results in the context of the Arab region. The first alarms the clarification of the impacts of the growth on performance by the ownership structure (Section 4.2.1), and the second concerns the explanation of the effects of risk-taking on performance by organizational differences and cultural aspects of risk-taking between women and men presidents (Section 4.2.2).

\subsubsection{The Effect of Growth Opportunities on Performance: Explanation by Ownership Structure in the Arab World}

By comparing the results of family businesses chaired by a woman and non-family businesses chaired by a woman, the factor of growth opportunities is significantly positive for the performance of non-family businesses chaired by women. This result shows the role played by family ownership when it comes to business performance. Similarly, the current research on family businesses including family factors shows that family business decision-makers are more reluctant to seize opportunities for fear of opening up capital to non-family shareholders, the fact that constitutes the 'one of the most non-financial objectives characterizing family businesses compared to non-family companies (Gomez-Mejia and al., 2007, 2011).

Then, other research gives a likely explanation that is based on the fact that the characteristics of family businesses can impact the determinants of family business performance, by failing to take advantage of market opportunities. Our result on samples of family and non-family businesses chaired by women, therefore, diverges from the thesis that family businesses can have performance advantages compared to non-family businesses (Maury, 2006).

Therefore, in family businesses, non-financial goals and the protection of non-financial family wealth are more important than financial goals (Gomez-Mejia and al., 2007). This is directly consistent with the transformational style generally adopted by women (Eagly \& Carli, 2012).

This line of argument notes that in the management of family-owned firms, female presidents can deal with obstacles, thus, the tasks of presidents appear to be problematic in family-owned. As a result, the dual role of the chairman in the family business (managing the business and meeting family obligations) can lead to a dilution of effort, which can give rise to obstacles, which in our case are represented by the failure to seize growth opportunities.

However, non-family firms are oriented to the maximization of financial wealth than family-owned businesses (Gomez Mejia and al., 2007; Allioui \& Habba, 2019; El Azizi, Habba \& Allioui, 2020). In this case, the president should protect the financial health of the company. As a result, the absence of social bonds among the directors and the presidents of the board increases the possibilities of seizing opportunities by non-family businesses. Indeed, in non-family businesses, the ability of the board to exert incentive control can compensate for the characteristics of the female style of leadership (Nekhili and al., 2018).

\subsubsection{The Risk-Taking Effects on Performance: The Role of the Gender of the President}

At this level, the discriminatory effect is represented by the financial balance of family businesses chaired by men compared to family businesses chaired by women. Our result shows that the use of debt as a sustainable financing solution is an explanatory element for the deteriorating performance of family-owned businesses chaired by men. This is clearly explained by the fact that sustainable resources (the numerator of the financial balance ratio) are made up of capital and debts, and since it has a significantly positive effect by capital (financial independence ratio), it is clear that the debt has a negative impact on the performance of family businesses chaired by men. Indeed, this can be explained by the fact that men tend to be opportunistic, and therefore take more risks by resorting to debt, which presents a risk-taking strategy unfavorable to the performance.

This result is consistent with empirical research that shows that females and males are distinct in their risk trade-offs. Female decision-makers have pragmatic preferences (Williams \& Narendran, 1999; Hallahan, Faff, \& McKenzie, 
2004; Neelakantan, 2010). In this context, evidence from studies and experiences shows that firms chaired by women are categorized by variations in incomes (the risk of variation) significantly lower than those controlled by men (Watson \& Robinson, 2003).

Besides, the differences in risk-taking between women and men are also based on cultural diversity (Thomas \& Mueller, 2000). In this context, the effects of family socialization in Arab society lead women to be much more prudent and pragmatic than men in their decision-making. Riadh Zghal (2000) confirms the confrontation of obstacles against women in Arab countries, through the appearance of an unprecedented reality socially and sociologically, namely the exercise of power by women executives is justified by their skills. But this power is difficult to be accepted by male collaborators in Arab countries. While the cultural environment may develop the proposition that men in staff are reluctant to accept the power of a female president, women's attitude towards power is characterized by pragmatism and prudence in decision-making to surprise those around them.

Also, the non-economic orientation of the female president in the case of family businesses pushes her to have a prudent personality aspect which is more accentuated by the family ownership (Schulze, Lubatkin, Dino, \& Buchholtz, 2001). Family business boards have fewer outside directors (Schulze and al., 2001). As a result, the hesitancy to risk by women can be intensified by the character of the prudent family property.

\section{Conclusion}

This paper examines the influence of the gender of the chairman on the performance of the family-owned business in the Arab world, and we provide evidence that the function of the chairman should be examined differently based on gender leadership style (Eagly \& Carli, 2012), and in relation to family issues (Smith and al., 2006). As far as we know, our paper is the original to study at the same time the relation between women's leadership at the level of the chairmanship of boards of directors, family ownership, and financial performance in the context of Arab countries.

From a sample of 318 companies, 152 of which are family businesses in the Arab world over the period 2011-2018, our results are consistent with the premises of leadership contingency theory, which postulates that the performance of the leadership is dependent on the type of company, the prerequisites of the leader's position, and cultural values. We show that the effects of women's leadership are accentuated by family ownership in the Arab context.

In our study, we find that female presidents boost the performance of family businesses. As a result, our hypothesis test results confirm the theory of transformational leadership, which indicates that women-controlled businesses have financial performance advantages in the context of Arab countries. Also, we find that the presidency of women is more precious for family-owned businesses. This possibly will result from the fact that female presidents in family businesses high-perform because they adopt the transformational style, which encompasses the needs and characteristics of Arab family businesses. Finally, based on panel tests, we perceive that women presidents in the Arab world are more efficient because they are more prudent and avoid excessive risk-taking strategies. Consequently, women presidents improve the performance of family businesses, while breaking stereotypical images of the women presidents' leadership style in the Arab world, and demonstrating that women are more prudent and talented. The opposite case leads to the fact that the failure of women sometimes in terms of seizing growth opportunities in family businesses in the Arab world is related to the distinctive facts of family businesses and not to women's leadership style.

Besides, we propose to present empirical evidence that the business environment is essential for the promotion of female leadership. In other words, regulations about female presidents in the Arab world need the support of appropriate measures, to eliminate the stereotypes which, block women's access to top management positions., rather than focusing only on legal requirements. In this context, initiatives, policies, attitudes, and changing the stereotypes of the Arab countries culture, can not only lead to a significant increase in the appointment of women as presidents of family businesses, but also the development of the businesses performance presided by women in Arab countries, through vocational training programs, and promoting changes in the cultural discrimination against women that continues to be dominant in the business in the Arab context, which is demonstrated by the rates we have presented in our introduction.

Our study presents also some limitations and ways for future research in the cultural context of the Arab world. The first limit is that in our research, we do not consider the remuneration of the president and, we have taken into consideration that female president has similar motivations as male president to care in the same way about their own and individual performance and the performance of the firm, whatever is the remuneration. The second limit is that we do not consider pragmatism and opportunism as a control variable, and we believe that these cultural traits play a role in the relation between the remuneration of women presidents and financial and organizational performance. 
The third limit is that we do not consider that the lower remuneration may push women to rationalize these pragmatic choices and balance the attention they give to business performance (which may be dependent on remuneration) with their own performance in private life, which limits our research considering that both gender leadership styles have the same incentives.

\section{References}

Allioui, A., \& Habba, B. (2019). Les effets des objectifs non financiers sur l'évaluation des entreprises familiales marocaines: une approche exploratoire. Moroccan Journal of Entrepreneurship, Innovation and Management, 4(1), 29-40. https://doi.org/10.48396/IMIST.PRSM/mjeim-v4i1.16002

Allioui, A., Habba, B., \& El Azizi, T. B. (2020). Transgenerational succession'effects on financial performance of listed family firms in the Arab Countries. European Scientific Journal, 16(25), 125. https://doi.org/10.19044/esj.2020.v16n25p125

Allouche, J., Amann, B., \& Garaudel, P. (2007). Performances et caractéristiques financières comparées des entreprises familiales et non familiales: le rôle modérateur de la cotation en bourse et du degré de contrôle actionnarial. Colloque Annuel 2007 AIMS, Montréal, 2007.

Bammens, Y., Voordeckers, W., \& Van Gils, A. (2011). Boards of directors in family businesses: A literature review and research agenda. International Journal of Management Reviews, 13(2), 134-152. https://doi.org/10.1111/j.1468-2370.2010.00289.x

Basly, S. (2007). Le conservatisme: une explication des choix financiers de la PME familiale. Article présenté au congrès international de l'AFFI (Association française de finances), Bordeaux.

Bass, B. M. (1999). Two decades of research and development in transformational leadership. European Journal of Work and Organizational Psychology, 8(1), 9-32. https://doi.org/10.1080/135943299398410

Burkart, M., Panunzi, F., \& Shleifer, A. (2003). Family firms. The Journal of Finance, 58(5), 2167-2201. https://doi.org/10.1111/1540-6261.00601

Capon, N., Farley, J. U., \& Hoenig, S. (1990). Determinants of financial performance: a Meta analysis. Management Science, 36(10), 1143-1159. https://doi.org/10.1287/mnsc.36.10.1143

Catalyst, K. C. (2012). Women CEOs of the Fortune 1000.

Chapple, L., \& Humphrey, J. E. (2014). Does board gender diversity have a financial impact? Evidence using stock portfolio performance. Journal of Business Ethics, 122(4), 709-723. https://doi.org/10.1007/s10551-013-1785-0

Debicki, B. J., Van De Graaff Randolph, R., \& Sobczak, M. (2017). Socioemotional wealth and family firm performance: a stakeholder approach. Journal of Managerial Issues, 29(1).

Dezsö, C. L., \& Ross, D. G. (2012). Does female representation in top management improve firm performance? A panel data investigation. Strategic Management Journal, 33(9), 1072-1089. https://doi.org/10.1002/smj.1955

Eagly, A. H., \& Carli, L. L. (2012). Women and the labyrinth of leadership. Contemporary Issues in Leadership, 147-162.

El Azizi, T. B., Habba, B., \& Allioui, A. (2020). Contribution à l'étude de l'impact des contraintes financières sur l'investissement des entreprises familiales dans le Monde Arabe. Revue Management Innovation, (2), 31-54.

Femmes, O. (2018). Rapport d'activités de 2017-2018, Bureau Multi-Pays pour le Maghreb, 2017-2018.

Fiedler, F. E. (1967). A theory of leadership effectiveness. Mcgraw-hill series in management.

Gomez-Mejia, L. R., Cruz, C., Berrone, P., \& De Castro, J. (2011). The bind that ties: Socioemotional wealth preservation in family firms. Academy of Management Annals, 5(1), 653-707. https://doi.org/10.5465/19416520.2011.593320

Gomez-Mejía, L. R., Haynes, K. T., Núñez-Nickel, M., Jacobson, K. J., \& Moyano-Fuentes, J. (2007). Socioemotional wealth and business risks in family-controlled firms: Evidence from Spanish olive oil mills. Administrative Science Quarterly, 52(1), 106-137. https://doi.org/10.2189\%2Fasqu.52.1.106

Gottardo, P., \& Moisello, A. M. (2015). The impact of socioemotional wealth on family firms' financial performance. Problems and Perspectives in Management, 13(1), 67-77.

Hallahan, T., Faff, R., \& McKenzie, M. (2004). An empirical investigation of financial risk tolerance. Financial Services Review, 13(1), 57-78. 
Jayawardena, L. C. (2012). Transformational leadership and emotional intelligence of graduate managers. Management and Production Engineering Review, 3, 28-33.

Labaki, R., Michael-Tsabari, N., \& Zachary, R. K. (2013). Emotional dimensions within the family business: Towards a conceptualization. In Handbook of research on family business (2nd ed.). Edward Elgar Publishing. https://doi.org/10.4337/9781781009383

Leach, P. (1990). Managing the Family Business in the UK. Stoy Hayward, London.

Maury, B. (2006). Family ownership and firm performance: Empirical evidence from Western European corporations. Journal of Corporate Finance, 12(2), 321-341. https://doi.org/10.1016/j.jcorpfin.2005.02.002

Neelakantan, U. (2010). Estimation and impact of gender differences in risk tolerance. Economic Inquiry, 8(1), 228-233. https://doi.org/10.1111/j.1465-7295.2009.00251.x

Nekhili, M., Chakroun, H., \& Chtioui, T. (2018). Women's leadership and firm performance: Family versus nonfamily firms. Journal of Business Ethics, 153(2), 291-316. https://doi.org/10.1007/s10551-016-3340-2

Oakley, J. G. (2000). Gender-based barriers to senior management positions: Understanding the scarcity of female CEOs. Journal of Business Ethics, 27(4), 321-334. https://doi.org/10.1023/A:1006226129868

Palvia, A., Vähämaa, E., \& Vähämaa, S. (2015). Are female CEOs and chairwomen more conservative and risk averse? Evidence from the banking industry during the financial crisis. Journal of Business Ethics, 131(3), 577-594. https://doi.org/10.1007/s10551-014-2288-3

Rosener, J. B. (1990). How women lead. Harvard Business Review, 68(6), 119-125.

Salloum, C., Jabbour, G., \& Mercier-Suissa, C. (2019). Democracy across gender diversity and ethnicity of Middle Eastern SMEs: how does performance differ?. Journal of Small Business Management, 57(1), 255-267.

Schulze, W. S., Lubatkin, M. H., Dino, R. N., \& Buchholtz, A. K. (2001). Agency relationships in family firms: Theory and evidence. Organization Science, 12(2), 99-116. https://doi.org/10.1287/orsc.12.2.99.10114

Shen, W., \& Joseph, D. L. (2020). Gender and leadership: A criterion-focused review and research agenda. Human Resource Management Review, 100765. https://doi.org/10.1016/j.hrmr.2020.100765

Smith, N., Smith, V., \& Verner, M. (2006). Do women in top management affect firm performance? A panel study of 2,500 Danish firms. International Journal of Productivity and Performance Management. https://doi.org/10.1108/17410400610702160

Thomas, A., \& Mueller, S. (2000). A case for comparative entrepreneurship: assessing the relevance of culture. Journal of International Business Studies, 31(2), 287-301. https://doi.org/10.1057/palgrave.jibs.8490906

Vallejo, M. C. (2009). Analytical model of leadership in family firms under transformational theoretical approach: An exploratory study. Family Business Review, 22(2), 136-150. https://doi.org/10.1177\%2F0894486508327892

Watson, J., \& Robinson, S. (2003). Adjusting for risk in comparing the performance of maleand female-controlled SMEs. Journal of Business Venturing, 18(6), 773-788. https://doi.org/10.1016/S0883-9026(02)00128-3

Williams, S., \& Narendran, S. (1999). Determinants of managerial risk: exploring personality and cultural differences. The Journal of Social Psychology, 139(1), 102-125. https://doi.org/10.1080/00224549909598365

Zghal, R. (2000). L'identification des freins à l'accès de la femme à la décision politique au Maroc. Rapport Final, Argos, Mars 2000.

Zhang, X. A., Li, N., Ullrich, J., \& Van Dick, R. (2015). Getting everyone on board: The effect of differentiated transformational leadership by CEOs on top management team effectiveness and leader-rated firm performance. Journal of Management, 41(7), 1898-1933. https://doi.org/10.1177\%2F0149206312471387

\section{Copyrights}

Copyright for this article is retained by the author(s), with first publication rights granted to the journal.

This is an open-access article distributed under the terms and conditions of the Creative Commons Attribution license (http://creativecommons.org/licenses/by/4.0/). 